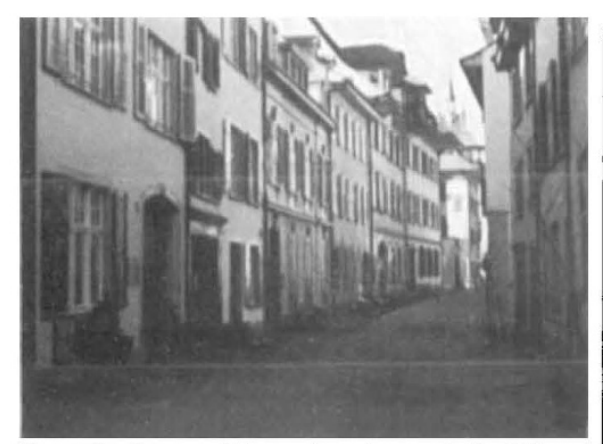

Some institutes of the university are in buildings of the fifteenth and sixteenth centuries.

This did not present a threat to the university until the late $1960 \mathrm{~s}$, when the fat years suddenly grew lean. The budget began to shrink and Basle-Stadt sought support elsewhere

Basle-Landschaft, which provides onethird of the students at the university, agreed to pay about one-fifth of the costs. It might have agreed to pay more if it had been given more say in university affairs. But there has never been much trust between the two half-cantons. As one professor puts it, "each side tries to blackmail the other". In a referendum, BasleLandschaft overwhelmingly rejected a proposal to reunite the split canton a few years ago, fearing domination by the inhabitants of Basle- Stadt.

Today, attracting more support from Basle-Landschaft, the Swiss federal government (which already makes a sizeable contribution) or some other canton is the university's main concern. The 200,000 inhabitants of Basle-Stadt do not provide a large enough tax base (even with help from the three pharmaceutical giants Ciba-Geigy, Hoffmann-La Roche and Sandoz) to keep the university, especially its medical clinics, going. (The clinics were excluded from the 1976 agreement.) The new rector Carl Rudolf Pfaltz, himself a professor of medicine, wrote earlier this month in apocalyptic terms about the future of the medical faculty if some broader base for the university clinic is not found.

But professors in other faculties (such as those at the Biozentrum) and even medical students do not feel threatened by the dispute. After all, research money comes primarily from outside, for example from the Swiss National Science Foundation.

The university's small size - - it had 6,712 students in winter $1987-88-$ - could be a limitation, but it is mitigated for faculty members by a cosy relationship with administrators, says astronomer Gustav Tammann.

Students have recently been granted a wider menu of courses by the Regio cooperative programme, established in 1987 by five universities in the upper Rhine valley - Basle, Freiburg and Karlsruhe in West Germany and Strasbourg and Mulhouse in France.

S.D.

\section{Basle Biozentrum}

\section{Still room for the individual}

THERE is an old saying in Switzerland: in Zurich, you have to be a banker; in Berne, a general, and in Basle, a professor. Jeff Schatz, himself a professor at the University of Basle Biozentrum (Biocentre), explains that in Basle, people value learning for learning's sake. Professors are regarded highly, but not in the authoritarian tradition of the German university; instead, social status emerges in the form of trust. "If you say you're a professor, they'll lend you money here", says Schatz.

After just 17 years, the Biozentrum has become a part of the academic tradition and has established a few traditions of its own. An interdisciplinary centre for biological research and teaching, the Biozentrum is a rare bird indeed in German-speaking Europe.

The open administrative structure of the Biozentrum is reflected in its architecture. A central atrium reaches from the ground floor to the top of the eight-storey building, a design that encourages the occupants to meet and talk. The centre was modelled on a Roman villa, says Alfred Pletscher. While director of research for Hoffmann-La Roche in the late 1960 s, Pletscher played midwife to the Biozentrum. He and others ensured that the organization was horizontal, with research groups limited to about fifteen people; a rotating directorship; and the opportunity for young researchers to work independently of the senior people. This last sets the Biozentrum apart from many European research establishments.

Although at first its proponents intended the Biozentrum to be primarily a research institution, this proved politically unworkable. Teaching has become an integral part of the programme, and a degree in cellular and molecular biology is an increasingly popular choice among students. Roughly half of Basle's 80 to 100 biology students each year do a 4-year Diplom course at the Biozentrum; the rest follow the traditional plan of zoology, botany and the like. A Diplom is nearly the equivalent of a US master's degree.

The highlight of the programme is a third-year laboratory and lecture course taught sequentially by Biozentrum professors (including industry researchers) on everything from biophysics to immunology. The course has proved a worthwhile investment, says current Biozentrum director Walter Gehring: "I find a lot of my graduate students there."

Research at the Biozentrum is internationally recognized. Best known, perhaps, are Gehring for his work on developmental genetics in Drosophila (fruit flies) and Schatz for his work on membrane biogenesis.

Two more bright spots are Werner

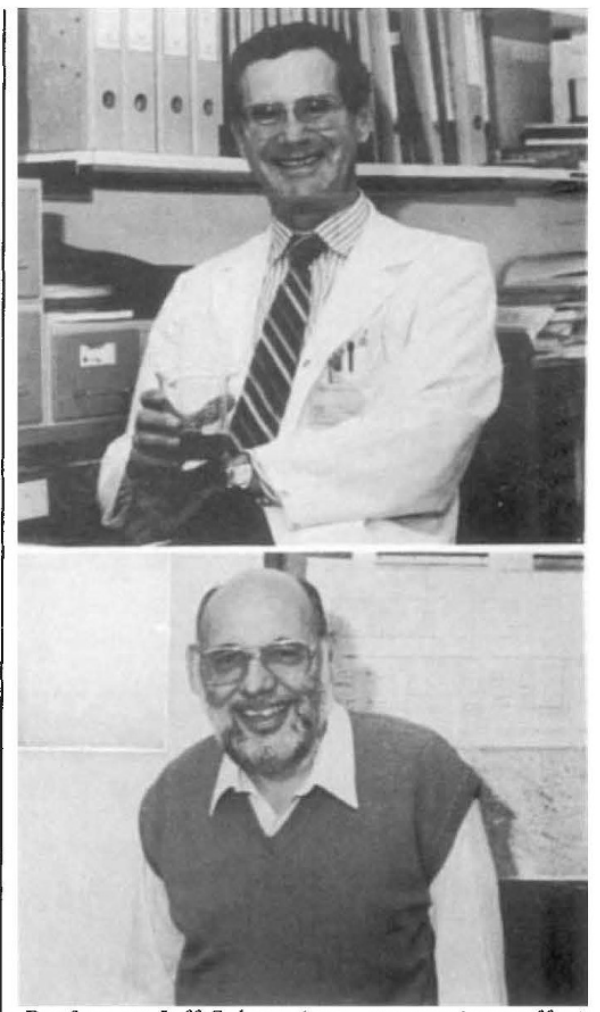

Professors Jeff Schatz (top, at morning coffee) and Walter Gehring.

Arber and Eduard Kellenberger. While working in Kellenberger's laboratory in Geneva, Arber was involved in the discovery of restriction enzymes, for which he later shared the Nobel prize. (These enzymes have become a fundamental tool in molecular biology and genetic engineering.) Arber and Kellenberger are among five Swiss out of the 16 group leaders at the Biozentrum.

More recently in the news was physician Urs Meyer, who was one of a group of US and Swiss researchers to identify a previously unrecognized genetic defect in 510 per cent of the white US and European population. The defect prevents the body from metabolizing an antihypertension drug because of the absence of intact copies of a liver cytochrome. The discovery has important implications for drug development and cancer research.

The list of other important groups at the Biozentrum would be too long to print.

Biozentrum professors are circumspect about the centre's future despite its impressive track record. "Our main task is to prevent hardening of the arteries", explains Schatz. "There was tremendous vitality when the Biozentrum was set up; researchers came from all over the world." The problem now is that many of the first crew will retire within a few years of each other by the late 1990s. Says Schatz, "We have to break the synchrony beforehand". 